\begin{tabular}{c} 
Journal of Business School \\
$2019,2(1): 80-98$ \\
DOI: $10.29226 / \mathrm{TR} 1010.2019 .56$ \\
\hline \\
Journal Homepage: https://www.journalbusiness.org \\
\hline
\end{tabular}

\title{
Corporate Social Responsibility and Non-Financial Organizational Performance in Etisalat Telecommunication Company United Arab Emirates
}

\author{
Dr. Mba Okechukwu Agwu \\ University of Modern Sciences Dubai, UA.E.
}

\begin{abstract}
The paper examined corporate social responsibility (CSR) and non-financial organizational performance in Etisalat telecommunication company United Arab Emirates. It views CSR as corporate activities that contribute to stakeholders' wellbeing. It assumes that stakeholderoriented CSR would improve non-financial organizational performance. The research question explores the relationship between stakeholder-oriented CSR and improved corporate image/reputation and enhanced products competitive advantage in Etisalat telecommunication company United Arab Emirates. The place of study consists of all the Etisalat offices in the seven emirates of U.A.E while the duration of study is between January and December 2017. A descriptive research design was used in executing the study, using 385 randomly selected employees of Etisalat in U.A.E, for questionnaire administration. The sample size of 385 was determined from a population of 10,000 employees consisting of 3,600 locals and 6,400 foreign nationals, using Yamane 1964 sample size determination formula at 5\% level of significance for sampling error. Results from the data analysis indicated that significant relationship exists between stakeholder-oriented CSR and improved corporate image/reputation and enhanced products competitive advantage in Etisalat telecommunication company United Arab Emirates and recommends among others: sustenance of the current CSR practices in Etisalat, continuous monitoring of changing expectations of key stakeholders to identify areas of support, continuous consultation with key stakeholders in decision making, continuous review of organizational CSR practices to align with industrial best practices and continuous provision of resources to sustain existing stakeholder-oriented CSR practices.
\end{abstract}

Keywords: CSR, organizational performance, Etisalat, stakeholders, corporate reputation.

\section{Introduction}

\subsection{Background of the Study}

Despite the existence of many research studies on the relationship between CSR and firm performance in many countries of the world, the paucity of similar research studies on corporate organizations in the United Arab Emirates prompts the need for this research. CSR is broadly understood as "actions that appear to further some social good, beyond the interest of the firm and that which is required by law" (McWilliams and Siegel, 2001). The firm's interests have been a great driver of CSR research, visible in the exploration of the link between CSR and firm's performance (Waddock and Graves, 1997). Evidence points to the 
increasing use of CSR programs as a way of achieving competitive advantage (Matten and Moon, 2008).

Thus CSR refers to voluntary corporate activities that are beneficial to stakeholders and the environment. Stakeholder-oriented CSR activities have been found to influence corporate reputation resulting in increased business performance (Ackerman, 1975). Firms adopt stakeholder-oriented CSR so as to be perceived as "socially responsible" to gain customer and other stakeholders support (Golob and Bartlett, 2007). Stakeholder-oriented CSR enable organizations to tailor their voluntary activities to the changing expectations of its stakeholders and the environment.

Stakeholders refer to any group or individual who would affect or be affected by the achievement of the organization's objectives (Freeman, 1984).They include: shareholders/investors, employees, customers, suppliers, governments or other public organizations that set laws and govern economic commerce (Clarkson, 1995), trade associations and environmental groups (Donaldson and Preston, 1995). They may be primary or secondary depending on whether they are directly or indirectly engaged in the economic activities of the organization. Managing and satisfying the interests of stakeholders may lead to significant improvements in corporate performance and sustainability (Freeman, 1984).

Since its inception in the UAE about four decades ago, Etisalat has adopted a stakeholderoriented CSR approach by consistently striving to foster innovation in the delivery of its telecommunication services. To this end, Etisalat continuously monitors and reviews its operational activities to identify and address specific CSR expectations of different stakeholders. For instance, it's recently launched enhanced mobile service packages offers its customers value for money, flexibility and price transparency. For example, its flagship business postpaid mobile package - addresses the specific needs of SMBs and large enterprises, Family Pack - addresses consumer data sharing, Global Data Plan -addresses data roaming/unlimited Wi-Fi worldwide while Data Boosters- addresses extension of mobile data allowance(Etisalat, 2016).

To address the needs of SMBs, who form the foundation of UAE's economic growth, Etisalat launched Business Quick Start - the first in a series of integrated Business in Box solutions that offer SMBs high-speed fixed broadband Internet, free voice minutes and a free smart device on a single, converged bill. A dedicated, state-of-the-art call centre for SMB customers has been launched that serves more than 72,000 SMBs and offers convenient and comprehensive ICT services and support, allowing SMBs to focus on their core competencies(Etisalat, 2016).

While there exist different organizational motivations for CSR activities, more researchers are beginning to understand and analyze CSR in the context of strategic performance and value creation shifting the focus of research from better financial performance to better overall performance in the long term. CSR can therefore be redefined as not going beyond the firm's interest but aligning it with stakeholders' interest, to create shared value (Kramer, 2011).It is against this background that it becomes pertinent to examine corporate social responsibility (CSR) and non-financial organizational performance in Etisalat telecommunication company United Arab Emirates.

\subsection{Statement of the Problem}

The satisfaction of stakeholders' interests is the mainstay of every business organization since no organization can exist without its stakeholder's support. Hence; the major challenge of every business organization is to create/sustain a good corporate image that will enhance organizational attractiveness in the minds of its stakeholders. The stakeholders are the source of 
supplies of raw materials, capital, labor, legal existence and patronage for the firm's products. Any business organization without its stakeholders support will experience a decline in productivity, sales, profitability, competitiveness and corporate image. Such an organization will sooner than later go into extinction or oblivion. When stakeholders lose confidence in a firm's performance, the firm loses its critical support structure and customer base (Lee, 2008). Customers stop buying products or go for legal suits, shareholders sell their stocks, employees do not perform, and environmental advocates sue (Wood, 1991), all of which directly affect firm performance. Hence business organizations like Etisalat should continuously carry out stakeholder-oriented CSR activities as a way of sustaining its business through creation of good corporate image/reputation that may result in gaining competitive advantage, increased patronage/sales and profitability.

\subsection{Research Objectives}

The objectives of the research are as stated:

To ascertain the extent of the relationship between stakeholder-oriented CSR and improved corporate image/reputation in Etisalat telecommunication company United Arab Emirates.

To determine the extent of the relationship between stakeholder-oriented CSR and enhanced products competitive advantage in Etisalat telecommunication company United Arab Emirates.

\subsection{Research Questions}

The increasing focus of recent CSR research activities on the alignment of corporate and stakeholders' interests has prompted the following research questions:

Does any significant relationship exist between stakeholder-oriented CSR and improved corporate image/reputation in Etisalat telecommunication company United Arab Emirates?

Does any significant relationship exist between stakeholder-oriented CSR and enhanced products competitive advantage in Etisalat telecommunication company United Arab Emirates?

\subsection{Research Hypotheses}

With regards to the above research questions, the following null hypotheses were formulated:

$H_{0}$ : There is no significant relationship between stakeholder-oriented CSR and improved corporate image/reputation in Etisalat telecommunication company United Arab Emirates.

Ho: There is no significant relationship between stakeholder-oriented CSR and enhanced products competitive advantage in Etisalat telecommunication company United Arab Emirates.

\subsection{Literature Review}

Several researches has focused on the relationship between CSR and firm performance while some studies reveal a positive relationship (Griffin and Mahon, 1997; McGuire et al., 1988; Waddock and Graves, 1997) others indicate a negative relationship (Bromiley and Marcus, 1989; Wright and Ferris, 1997) while some others have established no relationship between the two constructs (Aupperle et al., 1985; Teoh et al., 1999). Though a positive relationship has prevailed in many studies (Margolis and Walsh, 2003; Orlitzky et al., 2003), results still remain inconclusive which creates room for further research.

The influence of stakeholder-oriented CSR on firm performance can be understood with the help of three theories: (a) consumer inference making, (b) signaling theory, and (c) social 
identity theory. 'Consumer inference making' theory suggests that if a consumer knows that the manufacturer of the product is a responsible firm, s/he can infer positively about the product (Brown and Dacin, 1997). Such inferences induce consumer goodwill (Brown and Dacin, 1997; Handelman and Arnold, 1999) that influences purchase intention (Gildea, 1994; Owen and Scherer, 1993). 'Signaling' theory (Boulding and Kirmani, 1993; Kirmani, 1997) suggests that in situations where there is information asymmetry between buyers and sellers, consumers look for information/signals that distinguish companies performing well on attributes of interest compared to those performing poorly.

Signals such as warranties (Boulding and Kirmani, 1993) indicating reliability and higher quality of products enable consumers to decide between companies. Consumers associate higher product quality with proactive corporate citizenship (Maignan and Ferrell, 2001) and potential job-seekers value CSR record of companies as a signal for organizational attractiveness (Greening and Turban, 2000). 'Social identity' theory emphasizes that one's selfconcept is influenced by membership in different social organizations, including the company for which an individual works (Dutton et al., 1994). Employees' self-image is influenced by the image and reputation of their employers, consumers identify themselves with organizations or brands involved in discretionary citizenship and institutional investors like to be associated with socially responsible firms (Graves and Waddock, 1994). Such bonds of identification encourage positive evaluations of a firm's products, and reap value addition through customer loyalty, advocacy, positive words-of-mouth, and resilience to negative brand information (Hoeffler and Keller, 2002; Sen et al., 2006).

Alternatively, irresponsible behavior by firms agitates stakeholders. They often react by boycotting the company (Hayes and Pereira, 1990), reducing consumption of the company's products (Sen and Bhattacharya, 2001), initiating legal action against the company (Greeno and Robinson, 1992), and/or spreading bad words-of-mouth about irresponsible business practices (Clair et al., 1995). While improved stakeholder relations have the potential to improve a firm's reputation and performance, strained relations have the risk of adversely affecting a firm's performance.

Stakeholder (employee)-oriented CSR focuses on improving employees working conditions to enhance their job performance. Working conditions that respect human dignity, equality, and social protection result in a productive workplace (Somavia, 2000). Social responsibility of a company is a reputation factor and is an attractive force for potential and current employees (Turban and Greening, 1997). Ethical reputation contributes to job satisfaction and lower employee turnover by evoking positive reactions from employees' families and friends (Riordan et al., 1997). Because satisfied employees have higher morale and job motivation, they will work more effectively and efficiently (Berman et al., 1999) and contribute to higher levels of organizational effectiveness (Koys, 2001).Past studies established that better human resource management practices such as training and development of employees, their participation in problem solving, progressive remuneration policies and grievance procedures could reduce employee turnover and increases their productivity (Youndt et al., 1996).

Stakeholder (customer)-oriented CSR focuses on creating positive customer perception about product quality and safety, to increase sales or decrease costs associated with customer relationships (Waddock and Graves, 1997). In product retailing, market reactions are found to be negative for socially responsible companies. When customers are dissatisfied with a product or its associated services, investors apprehend that negative customer reactions in the form of decreased patronage, lawsuits, or both, will directly affect the bottom line (Davidson and Worell, 1988). Yoon et al (1993) observed that if a company's CSR activities are perceived as 
positive by consumers; its products are assumed to be of superior quality. On the other hand, if perceived as negative, consumers will automatically assume their products are of poor quality.

Stakeholder (investor)-oriented CSR focuses on sound corporate governance standards. Investors show a willingness to pay a premium for the stocks of well-governed companies in contract to poorly governed companies (Coombes and Watson, 2000). Positive relations had been found between corporate governance and stock price performance/financial ratios in emerging markets. Companies ranked in the top quarter of corporate governance yield a better average return on capital employed than companies ranked at the bottom half (CLSA, 2000).

Stakeholder (community)-oriented CSR focuses on community relationships and participation in social and economic development issues. When firms focus their social actions on communities in and around their area of operation, they reap the benefits of a socially responsible image among their employees and the local community (Husted, 2003). Though past evidence suggests a negative relation between CSR towards the community and firm performance (Berman et al., 1999), it has been observed that investment in community development activities help a firm to obtain competitive advantages through tax savings, decreased regulatory burden, and improvements in the quality of local labor (Waddock and Graves, 1997).

Stakeholder (environment)-oriented CSR focuses on environmental protection. Research on environmental proactivity has not been conclusive (Christman, 2000). But recent research studies have linked environmental commitment with enhanced profitability, particularly in high growth industries (Russo and Fouts, 1997). Evidence suggests that proactive environmental management enhances a firm's market value, reputation and firm performance (Alvarez et al., 2001). The impact of firms' proactive environmental practices on market share, profitability, and return on investment is better in environment conscious companies than notso-conscious ones (Ahmed et al., 1998).

Stakeholder (suppliers)-oriented CSR focuses on companies concentrating on their core competencies and outsourcing other functions to suppliers. Recent years have seen growing importance of suppliers' issues such as health and safety, environmental impact, community involvement, and the payment of living wages to employees at both outsourced plant locations and home locations of suppliers. By ensuring suppliers adherence to good CSR standards, a firm sends a strong signal of zero tolerance for irresponsible CSR activities. While the influence of CSR on financial performance is a widely researched area, its influence on non-financial performance is sparsely investigated. Hence, this study is focused on nonfinancial organizational performance in Etisalat telecommunication company United Arab Emirates.

\subsection{Conceptual Framework}

Though CSR may be perceived as corporate obligations to its stakeholders, it is generally described as a firm's commitment to improving the well-being of a community through discretionary business practices (Kotler, 2005). According to Carroll (1979) corporate CSR obligations can be classified into four main groups: economic, legal, ethical, and philanthropic. Economic responsibilities include duties to make profit, provide safe goods and services, pay employees and increase value of shareholders investments. Legal responsibilities include duties to obey societal rules and regulations. Ethical responsibilities include duties to obey societal ethical norms and behave in a socially responsible manner. Philanthropic responsibilities include duties to promote human welfare and enhance societal quality of life. 
Bhattacharya and Sen (2004) explored the relationship between CSR activities and customer outcomes and categorized them into six domains: employee support (e.g., concern for safety, job security, profit-sharing, and union relations); diversity (e.g., gender, race, family, sexual orientation, and disability); environment (e.g., environment friendly products, hazardous waste management, animal testing, pollution control, and recycling); community support (e.g., support of arts and health programs, educational and housing initiatives, and generous giving); non-domestic operations (e.g., overseas labor practices); and product (e.g., product safety, marketing controversies, and antitrust disputes).

From the above discourse, it is obvious that CSR is concerned with voluntary corporate societal obligations, hence, the more CSR activities a company executes, the more economic benefits it enjoys since people tends to be more sensitive to companies that act responsibly than those that act irresponsibly (Porter and Kramer, 2006).

The conceptual framework of this research is based on Carroll's (1979/1991) Bhattacharya and Sen's (2004), and Oskamp's (1997) research studies, which states that stakeholders will almost always favor a company that acts responsibly through setting up operational stakeholderoriented CSR policies beneficial to the local community and society at large. These stakeholders will reciprocate by feeling strongly and positively about the company, which they will then voluntarily support in a number of ways such as eagerly buying its products, promoting it to others and favorably evaluating it. The Carroll (1979) and Bhattacharya and Sen (2004) conceptual model is as stated below:

Figure 1 - The Conceptual Framework of stakeholder-oriented CSR Policies

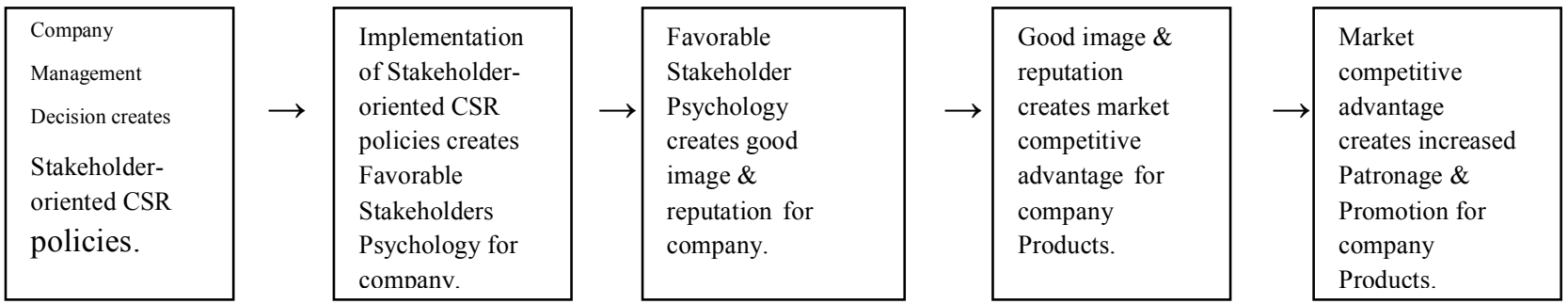

Source: Adapted from Carroll (1979) and Bhattacharya and Sen (2004)

Figure 1 shows that Stakeholders-oriented CSR policies arises from company management decision while its implementation creates favorable stakeholders psychology for company which in turn leads to good image \& reputation for company that results in market competitive advantage for company products that finally yields increased patronage \& promotion for company Products.

\subsection{Theoretical Framework}

This research is based on Freeman (1984) stakeholders' theory which states that consideration of key stakeholders values, sentiments and expectations in a firm's CSR activities will lead to significant improvements in corporate performance and sustainability. Hence, the effectiveness of organizational CSR activities depends on how well managers understand key stakeholders' interests and appropriately responds to them (Miles et al., 2006; Wing-Hung Lo et al., 2010). Prior to designing and implementing organizational CSR policies, managers should undertake a variety of marketing research and environmental scanning activities to identify and understand stakeholders' interests/expectations which are subsequently incorporated into organizational CSR programs.

Stakeholder orientation requires that firms actively monitor and engage with their stakeholder environment, which has been likened to expanding on the traditional marketing orientation 
approach (Ferrell et al., 2010). In fact, many companies have conducted CSR programs as a way of promoting socially responsible actions and effectively responding to stakeholders' demands (Maignan and Ferrell, 2004). Therefore CSR is most effective at improving consumers' attitude towards the company, enhancing consumers loyalty as well as downsizing the level of consumers skepticism, i.e., reducing consumers' concerns and doubts regarding the company's products and services (Pirsch et al., 2007).

Corporate reputation is an organization's identity in the minds of its stakeholders; hence a firm's CSR activities play a critical role in assessing its reputation (Lii and Lee, 2012). Research has shown that there is an association between corporate reputation and business performance, in other words, the more positive the reputation, the higher the performance, with positive perceptions motivating consumer purchase and developing positive brand associations (Neville et al., 2005).

Fombrun and Shanley (1990) determined that a firm's good reputation attracts investors and better qualified personnel, lowers the cost of capital and enhances its competitive ability. Herremans et al. (1993) found that companies with better CSR reputations outperform those with poorer reputations and provide investors with higher stock market returns. Firms with good reputation also command higher prices, generate more employee loyalty and greater productivity, have bargaining power with their suppliers, more stable revenues, and are less exposed to crises (Fombrun, 1996).

The impact of CSR activities on corporate reputation is measured by managers' perceptions of how an organization is being perceived across a set of stakeholders in general, rather than by each specific stakeholder, which is often done when assessing CSR-related activities (Maignan et al., 2011). This managerial perspective identifies the dimensions and attributes of corporate self-perception, reflecting on what management believes key stakeholders may consider as realistic, meaningful and long-lasting.

\section{Research Methods}

The scope of this research is limited to the three categories of administrative staff (management staff, operations staff and support staff) working in all the Etisalat offices across the seven emirates of U.A.E. It is assumed that responses obtained from the sample respondents would be representative of the opinions of all the three categories of administrative staff on their perception of corporate social responsibility (CSR) and nonfinancial organizational performance in their company. The duration of the study is between January and December 2017. The key aspect of the study is the use of cross sectional survey research design in generating the required primary data.

A sample of 385 randomly selected respondents from a population of 10,000 Etisalat employees consisting of 1,610 management staff, 6,340 operations staff and 2,050 support staff across the seven emirates of U.A.E. was used for questionnaire administration. The sample size of 385 was determined from the population size using Yamane 1964 sample size determination formula at $5 \%$ level of significance for sampling error. The sample respondents were selected using shuffling of cards method (without replacement) in which all the names of the three categories of employees' were each separately written on small cards and the name at the topmost of each of the three group of cards was selected each time, the cards were shuffled until all the sample respondents were selected.

Data collected were analyzed using descriptive and inferential statistics. The questionnaire was designed to obtain a fair representation of the opinions of 385 sample respondents (62 management staff, 244 operations staff and78 support staff) using a four-point Likert type 
scale. The questionnaire responses of the sample respondents were presented using tables while formulated hypotheses were tested using analysis of variance (ANOVA). A total of 385 copies of the questionnaire were administered, collected and used for the analysis.

\subsection{Calculation of Sample Size}

The sample size of 385 was determined from the population of 10,000 Etisalat employees across the seven emirates of U.A.E. using Yamane (1964) formula for sample size determination thus:

$$
\mathrm{n}=\frac{\mathrm{N}}{1+\mathrm{N}(\mathrm{e})^{2}}
$$

Where: $\mathrm{n}=$ sample size, $\mathrm{N}=$ population size, $\mathrm{e}=$ level of significance/sample error factor.

$$
\mathrm{n}=\frac{10,000}{1+10,000(0.05)^{2}}=\frac{10,000}{26} \quad=384.62=\mathbf{3 8 5}
$$

\section{Results and Discussions}

\subsection{Distribution of Responses on Research Questions}

\subsubsection{Question number 1}

Does any significant relationship exist between stakeholder-oriented CSR and improved corporate image/reputation in Etisalat telecommunication company United Arab Emirates?

Table 1 shows that questions: 1, 2, 3, 4, and 5 with varying mean scores of 2.99, 2.86, 2.78, 2.77 and 3.05 were above the weighted average of 2.5. The table further revealed a grand mean score of 2.89 indicating a strong evidence of the existence of a significant relationship between stakeholder-oriented CSR and improved corporate image/reputation in Etisalat telecommunication company United Arab Emirates. This conclusion is buttressed by the Bhattacharya and Sen's (2004), and Oskamp's (1997) research studies, which states that stakeholders will almost always favor a company that acts responsibly through setting up operational stakeholder-oriented CSR policies beneficial to the local community and society at large. These stakeholders will reciprocate by feeling strongly and positively about the company, which they will then voluntarily support in a number of ways such as eagerly buying its products, promoting it to others and favorably evaluating it. This conclusion is also supported by the observation of Herremans et al. (1993) that companies with better CSR reputations outperform those with poorer reputations and provide investors with higher stock market returns.

$$
\text { Mean Score }=\frac{4 n 4+3 n 3+2 n 2+1 n 1}{(n 4+n 3+n 2+n 1)}
$$

Where $\mathrm{n} 1, \mathrm{n} 2, \mathrm{n} 3$ and $\mathrm{n} 4$ are the respective number of responses obtained from each of the four options provided while1, 2, 3 and 4 respectively represent the weights (SA (4), A (3), D (2) \& SD (1) attached to each of the four options. 
Journal of Business School, vol.2, issue.1, pp.80-98

Table1. Mean responses on the relationship between stakeholder-oriented CSR and improved corporate image/reputation in Etisalat telecommunication company United Arab Emirates $(n=385)$

\begin{tabular}{|c|c|c|c|c|c|c|c|}
\hline$\overline{\mathrm{S} / \mathrm{No} .}$ & Research Questions & $\mathrm{SA}(4)$ & $\mathrm{A}(3)$ & $\mathrm{D}(2)$ & $\mathrm{SD}(1)$ & $\begin{array}{l}\text { Total } \\
\text { Responses }\end{array}$ & $\begin{array}{l}\text { Mean } \\
\text { Score }\end{array}$ \\
\hline \multirow[t]{2}{*}{1.} & $\begin{array}{l}\text { Has the adoption of } \\
\text { stakeholder-oriented CSR }\end{array}$ & 155 & 105 & 90 & 35 & & \\
\hline & $\begin{array}{l}\text { attracted } \\
\text { favorable reactions from } \\
\text { its stakeholders? }\end{array}$ & 620 & 315 & 180 & 35 & 1150 & 2.99 \\
\hline \multirow[t]{2}{*}{2.} & $\begin{array}{l}\text { Has the adoption of } \\
\text { stakeholder-oriented }\end{array}$ & 135 & 110 & 90 & 50 & & \\
\hline & $\begin{array}{l}\text { CSR increased the } \\
\text { firm's approval rating } \\
\text { among its stakeholders? }\end{array}$ & 540 & 330 & 180 & 50 & 1100 & 2.86 \\
\hline \multirow[t]{2}{*}{3.} & $\begin{array}{l}\text { Has the adoption of } \\
\text { stakeholder-oriented }\end{array}$ & 125 & 105 & 100 & 55 & & \\
\hline & $\begin{array}{l}\text { CSR increased } \\
\text { stakeholders trust } \\
\text { for the firm's activities? }\end{array}$ & 500 & 315 & 200 & 55 & 1070 & 2.78 \\
\hline 4. & $\begin{array}{l}\text { Has the adoption of } \\
\text { stakeholder-oriented } \\
\text { CSR reduced the level } \\
\text { of skepticism for the } \\
\text { firm's products? }\end{array}$ & 140 & 255 & 180 & 70 & 1065 & 2.77 \\
\hline \multirow[t]{2}{*}{5.} & $\begin{array}{l}\text { Has the adoption of } \\
\text { stakeholder-oriented } \\
\text { CSR reduced the level of } \\
\text { complaints for the } \\
\text { firm's activities? }\end{array}$ & 170 & 105 & 140 & 40 & 1175 & 3.05 \\
\hline & Grand Mean & & & & & & 2.89 \\
\hline
\end{tabular}

Source: Field Survey, 2017.

\subsubsection{Question number 2}

Does any significant relationship exist between stakeholder-oriented CSR and enhanced products competitive advantage in Etisalat telecommunication company United Arab Emirates? 
Table 2 shows that questions: 6, 7, 8, 9, and 10 with mean scores of 2.74, 3.00, 2.86, 2.71 and 2.99 were above the weighted average of 2.50 . The grand mean of 2.86 shows that there is a strong evidence of a significant relationship between stakeholder-oriented CSR and enhanced products competitive advantage in Etisalat telecommunication company United Arab Emirates. This conclusion is buttressed by the observation of Pirsch et al., (2007) that CSR is most effective at improving consumers' attitude towards the company, enhancing consumers' loyalty as well as downsizing the level of consumers' skepticism, i.e., reducing consumers' concerns and doubts regarding the company's products and services. This conclusion is also supported by Brown and Dacin (1997) Consumer inference making theory, which suggests that if a consumer knows that the manufacturer of a product is a responsible firm, s/he can infer positively about the product. Such inferences induce consumer goodwill.

Table 2: Mean responses on the relationship between stakeholder-oriented CSR and enhanced products competitive advantage in Etisalat telecommunication company United Arab Emirates (n=385).

\begin{tabular}{|c|c|c|c|c|c|c|c|}
\hline $\mathrm{S} / \mathrm{No}$ & Research Questions & $\mathrm{SA}(4)$ & A (3) & $\mathrm{D}(2)$ & $\mathrm{SD}(1$ & $\begin{array}{l}\text { Total } \\
\text { Responses }\end{array}$ & $\begin{array}{l}\text { Mean } \\
\text { Score }\end{array}$ \\
\hline \multirow[t]{2}{*}{6.} & $\begin{array}{l}\text { Has the adoption of } \\
\text { stakeholder-oriented }\end{array}$ & 130 & 95 & 90 & 70 & & \\
\hline & $\begin{array}{l}\text { CSR increased market } \\
\text { preference of your products? }\end{array}$ & 520 & 285 & 180 & 70 & 1055 & 2.74 \\
\hline \multirow[t]{2}{*}{7.} & $\begin{array}{l}\text { Has the adoption of } \\
\text { stakeholder-oriented }\end{array}$ & 160 & 105 & 80 & 40 & & \\
\hline & $\begin{array}{l}\text { CSR increased market } \\
\text { demand of your products? }\end{array}$ & 640 & 315 & 160 & 40 & 1155 & 3.00 \\
\hline \multirow[t]{2}{*}{8.} & Has the adoption of & 140 & 100 & 95 & 50 & & \\
\hline & $\begin{array}{l}\text { stakeholder-oriented } \\
\text { CSR increased market } \\
\text { attractiveness of your products? }\end{array}$ & 560 & 300 & 190 & 50 & 1100 & 2.86 \\
\hline \multirow[t]{2}{*}{9} & $\begin{array}{l}\text { Has the adoption of } \\
\text { stakeholder-oriented }\end{array}$ & 120 & 105 & 90 & 70 & & \\
\hline & $\begin{array}{l}\text { CSR increased market } \\
\text { Class of your products? }\end{array}$ & 480 & 315 & 180 & 70 & 1045 & 2.71 \\
\hline \multirow[t]{3}{*}{10} & $\begin{array}{l}\text { Has the adoption of } \\
\text { stakeholder-oriented }\end{array}$ & 165 & 95 & 80 & 45 & & \\
\hline & $\begin{array}{l}\text { CSR increased market } \\
\text { edge of your products? }\end{array}$ & 660 & 285 & 160 & 45 & 1150 & 2.99 \\
\hline & Grand Mean & & & & & & 2.86 \\
\hline
\end{tabular}

Source: Field Survey, 2017.

\subsection{Test of the First Hypothesis}

Ho: There is no significant relationship between stakeholder-oriented CSR and improved corporate image/reputation in Etisalat telecommunication company United Arab Emirates.

H1: There is a significant relationship between stakeholder-oriented CSR and improved 
Journal of Business School, vol.2, issue.1, pp.80-98

corporate image/reputation in Etisalat telecommunication company United Arab Emirates.

Table 3: Computation of Statistical Variables on the First Hypothesis from table 1

\begin{tabular}{lllllllll}
\hline S/No. & \multicolumn{2}{l}{ Strongly Agree } & Agree & \multicolumn{2}{c}{ Disagree } & \multicolumn{2}{c}{ Strongly Disagree } \\
\hline & $\mathrm{X}$ & $\mathrm{X} 2$ & $\mathrm{X}$ & $\mathrm{X} 2$ & $\mathrm{X}$ & $\mathrm{X} 2$ & $\mathrm{X}$ & $\mathrm{X} 2$ \\
1 & 155 & 24025 & 105 & 11025 & 90 & 8100 & 35 & 1225 \\
2 & 135 & 18225 & 110 & 12100 & 90 & 8100 & 50 & 2500 \\
3 & 125 & 15625 & 105 & 11025 & 100 & 10000 & 55 & 3025 \\
4 & 140 & 19600 & 85 & 7225 & 90 & 8100 & 70 & 4900 \\
5 & 170 & 28900 & 105 & 11025 & 70 & 4900 & 40 & 1600 \\
Totals & 725 & 106375 & 510 & 52400 & 440 & 39200 & 250 & 13250 \\
\hline
\end{tabular}

Source: Survey Data, 2017.

Calculation of total sum of squares (SST)

$\mathrm{SST}=\Sigma\left(\boldsymbol{X}_{i j}-\boldsymbol{X}_{i}\right)^{2}$

$\sum X^{2}=106375+52400+39200+13250=\mathbf{2 1 1}, \mathbf{2 2 5}$

$-\left(\sum X\right)=(725+510+440+250)^{2} \quad=\mathbf{1 8 5 , 2 8 1}$

N 20

SST $=211,225-185,281=25,944$

Calculation of between group sum of squares (SSB)

$\mathrm{SSB}=\Sigma(\overline{\boldsymbol{X}}-\boldsymbol{X} \overline{\bar{T}}$

$\begin{array}{cccc}\frac{-(\Sigma X)^{2}}{\mathrm{n}} & =\frac{(725)^{2}}{5}+\frac{(510)^{2}}{5}+\underline{(440)^{2}}+\frac{(250)^{2}}{5} & 5 \\ & =105125+52020+38720+12500=\mathbf{2 0 8 , 3 6 5} \\ -\frac{(\Sigma X)^{2}}{N} & =-\frac{(725+510+440+250)^{2}}{20} & =\mathbf{1 8 5 , 2 8 1}\end{array}$

SSB $=208,365-185,281=\mathbf{2 3 , 0 8 4}$

Calculation of within group sum of squares (SSw)

SSw $=\Sigma(X i j-X)^{2}$ or SSW $=$ SST - SSB

SSw $=$ SST - SSB $=25,944-23,084=2860$

Calculation degrees of freedom

SST $\mathbf{d f}=\mathrm{N}-1=20-1=\mathbf{1 9}$ 
SSB df $=\mathrm{n}-1=4-1=3$

SSW df $=n-1+n-1+n-1+n-1=4 n-4=4(5)-4=20-4=16$

\section{Calculation of Variances}

Between group variance $\left(\mathbf{S B}^{2}\right)=\underline{\text { Between group sum of squares (SSB) }}$

Between group degree of freedom

$$
\mathrm{SB}^{2}=\frac{23084}{3}=7695
$$

Within group variance $\left(\mathbf{S W}^{2}\right)=$ Within group sum of squares $(\mathrm{SSW})$

Within group degree of freedom

$$
\mathrm{SW}^{2}=\frac{2860}{16}=\mathbf{1 7 9}
$$

F-value $=\boldsymbol{F}_{\boldsymbol{d f ^ { \prime } f ^ { \prime } \mathbf { 2 }}}=\underline{\boldsymbol{S B}^{2}}=\underline{\text { Between group variance }}=\underline{7695}=\mathbf{4 2 . 9 9}$

$\boldsymbol{S} \boldsymbol{W}^{2}$ Within group variance 179

Table 4 shows that calculated F-Value of 42.99 resulted from the relationship between stakeholder-oriented CSR and improved corporate image/reputation in Etisalat telecommunication company United Arab Emirates. This calculated F-Value is significant since it is greater than the critical F-Value of $\mathbf{3 . 2 4}$ given 3/16 degree of freedom at 0.05 level of significance. Hence, the null hypothesis is rejected while the alternative is accepted. This shows that there is a significant relationship between stakeholder-oriented CSR and improved corporate image/reputation in Etisalat telecommunication company United Arab Emirates.

Table 4: Computation of Analysis of Variance on the relationship stakeholder-oriented CSR and improved corporate image/reputation in Etisalat telecommunication company United Arab

Emirates.

\begin{tabular}{lllllll}
\hline $\begin{array}{l}\text { Source of } \\
\text { variance }\end{array}$ & $\begin{array}{l}\text { Sum of } \\
\text { squares }\end{array}$ & $\begin{array}{l}\text { Degree } \\
\text { of } \\
\text { freedom }\end{array}$ & $\begin{array}{l}\text { Mean sum of } \\
\text { squares }\end{array}$ & $\begin{array}{l}\text { Calculated } \\
\text { F-value }\end{array}$ & $\begin{array}{l}\text { Table } \\
\text { critical } \\
\text { F-value }\end{array}$ & Decision \\
\hline $\begin{array}{l}\text { Between } \\
\text { group }\end{array}$ & 23084 & 3 & 7695 & 42.99 & 3.24 & $\begin{array}{l}\text { Ho: } \\
\text { Wejected }\end{array}$ \\
$\begin{array}{l}\text { Within } \\
\text { group }\end{array}$ & 2860 & 16 & 179 & & & \\
Total & 25944 & 19 & & & & \\
\hline
\end{tabular}

Source: Statistical Computation and Table 3.

\subsection{Test of the Second Hypothesis}

Ho: There is no significant relationship between stakeholder-oriented CSR and enhanced products competitive advantage in Etisalat telecommunication company United Arab Emirates

H1: There is a significant relationship between stakeholder-oriented CSR and enhanced products competitive advantage in Etisalat telecommunication company United Arab Emirates 
Journal of Business School, vol.2, issue.1, pp.80-98

Table 5. Computation of Statistical Variables on the second Hypothesis from table 2

\begin{tabular}{lllllllll}
\hline & \multicolumn{1}{c}{} & \multicolumn{3}{c}{ Disagre } \\
S/No. & \multicolumn{1}{c}{ Strongly } & Agree & Agree & & $\mathrm{e}$ & \multicolumn{2}{c}{ Strongly Disagree } \\
\hline & $\mathrm{X}$ & $\mathrm{X} 2$ & $\mathrm{X}$ & $\mathrm{X} 2$ & $\mathrm{X}$ & $\mathrm{X} 2$ & $\mathrm{X}$ & X2 \\
6 & 130 & 16900 & 95 & 9025 & 90 & 8100 & 70 & 4900 \\
7 & 160 & 25600 & 105 & 11025 & 80 & 6400 & 40 & 1600 \\
8 & 140 & 19600 & 100 & 10000 & 95 & 9025 & 50 & 2500 \\
9 & 120 & 14400 & 105 & 11025 & 90 & 8100 & 70 & 4900 \\
10 & 165 & 27225 & 95 & 9025 & 80 & 6400 & 45 & 2025 \\
Totals & 715 & 103725 & 500 & 50100 & 435 & 38025 & 275 & 15925 \\
\hline
\end{tabular}

Source: Survey Data, 2017.

Calculation of total sum of squares (SST)

$\mathrm{SST}=\Sigma\left(\boldsymbol{X}_{i j}-\boldsymbol{X}_{i}\right)^{2}$

$\Sigma X^{2}=103725+50100+38025+15925=\mathbf{2 0 7}, 775$

$-\left(\sum X\right)^{2}=(715+500+435+275)^{2} \quad=\mathbf{1 8 5 , 2 8 1}$

$\mathrm{N} \quad 20$

SST $=207,775-185,281=22,494$

Calculation of between group sum of squares (SSB)

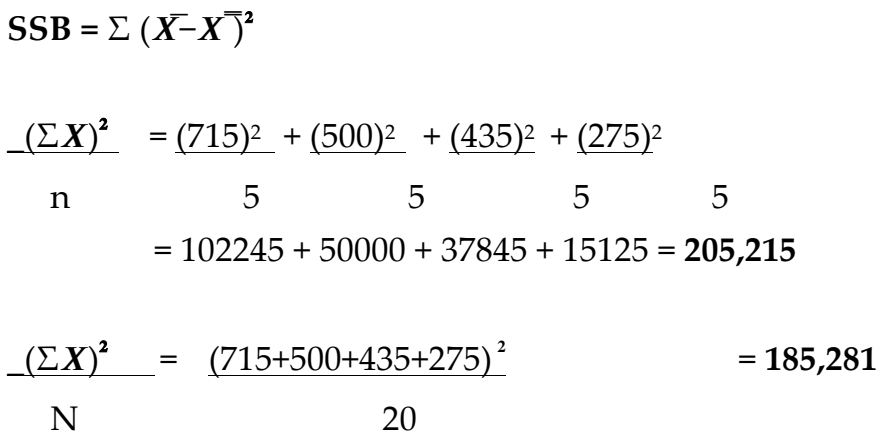

SSB=205,215 $-185,281=\mathbf{1 9 , 9 3 4}$

Calculation of within group sum of squares (SSw)

SSw $=\Sigma(X i j-X)^{2}$ or SSW $=$ SST - SSB

SSw $=$ SST - SSB $=22,494-19,934=2560$

Calculation degrees of freedom

SST $\mathbf{d f}=\mathrm{N}-1=20-1=19$

SSB $\mathbf{d f}=\mathrm{n}-1=4-1=3$ 
SSW df $=n-1+n-1+n-1+n-1=4 n-4=4(5)-4=20-4=16$

Calculation of Variances

Between group variance $\left(\mathrm{SB}^{2}\right)=$ Between group sum of squares (SSB)

Between group degree of freedom

$$
\mathrm{SB}^{2}=\frac{19934}{3}=6645
$$

Within group variance $\left(\mathrm{SW}^{2}\right)=$ Within group sum of squares (SSW)

Within group degree of freedom

$$
\mathrm{SW}^{2}=\frac{2560}{16}=\mathbf{1 6 0}
$$

$$
\begin{aligned}
& \text { F-value }=\boldsymbol{F}_{{\boldsymbol{d f 1 ^ { \prime }}}^{\prime} \mathbf{2}}=\underline{\boldsymbol{S} \boldsymbol{B}^{2}}=\underline{\text { Between group variance }}=\underline{6645}=\mathbf{4 1 . 5 3} \\
& S \boldsymbol{W}^{2} \text { Within group variance } 160
\end{aligned}
$$

Table 6 shows that calculated F-Value of 41.53 resulted from the relationship between stakeholder-oriented CSR and enhanced products competitive advantage in Etisalat telecommunication company United Arab Emirates. This calculated F-Value is significant since it is greater than the critical F-Value of 3.24 given 3/16 degree of freedom at 0.05 level of significance. Hence, the null hypothesis is rejected while the alternative is accepted. This shows that there is a significant relationship between stakeholder-oriented CSR and enhanced products competitive advantage in Etisalat telecommunication company United Arab Emirates.

Table 6: Computation of Analysis of Variance on the relationship between stakeholderoriented CSR and enhanced products competitive advantage in Etisalat telecommunication company United Arab Emirates

\begin{tabular}{lllllll}
\hline $\begin{array}{l}\text { Source of } \\
\text { variance }\end{array}$ & $\begin{array}{l}\text { sum of } \\
\text { squares }\end{array}$ & $\begin{array}{l}\text { Degree } \\
\text { of } \\
\text { freedom }\end{array}$ & $\begin{array}{l}\text { Mean } \\
\text { sum of } \\
\text { squares }\end{array}$ & $\begin{array}{l}\text { Calculate } \\
\text { F-value }\end{array}$ & $\begin{array}{l}\text { Table } \\
\text { critical } \\
\text { F-value }\end{array}$ & Decision \\
\hline $\begin{array}{l}\text { Between } \\
\text { group }\end{array}$ & 19934 & 3 & 6645 & 41.53 & 3.24 & Ho: \\
$\begin{array}{l}\text { Within } \\
\text { group }\end{array}$ & 2560 & 16 & 160 & & & Rejected \\
Total & 22494 & 19 & & & & \\
\hline
\end{tabular}

Source: Statistical Computation and Table 5

\section{Conclusion and Recommendations}

The paper discussed corporate social responsibility (CSR) and non-financial organizational performance in Etisalat telecommunication company United Arab Emirates. It assumes that stakeholder-oriented CSR would improve non-financial organizational performance. The three major findings of the research are as follows:

- Stakeholder-oriented CSR could improve consumers' attitude towards the firm's products 
by reducing the level of skepticism.

- There is a significant relationship between stakeholder-oriented CSR and enhanced products competitive advantage in Etisalat telecommunication company United Arab Emirates.

- There is a significant relationship between stakeholder-oriented CSR and improved corporate image/reputation in Etisalat telecommunication company United Arab Emirates.

Arising from the findings of this paper, it is suggested that the management of Etisalat should take the following measures to sustain the current gains of its stakeholder-oriented CSR activities:

(I)Sustenance of the current CSR practices: The current CSR efforts should be sustained through the introduction of different types of incentives for personnel responsible for the execution of corporate CSR responsibilities.

(II) Continuous monitoring of key stakeholders expectations: Since the expectations of key stakeholders are constantly changing there is a need for a monitoring committee to align corporate CSR activities with the current expectations of key stakeholders.

(III) Continuous review of organizational CSR policies and practices: Organizational CSR policies and practices should be reviewed regularly to align them with current industrial best practices.

(IV) Continuous consultation with key stakeholders: Key stakeholders should be consulted on a regular basis to obtain inputs for CSR decision making.

(V) Continuous provision of resources: Resources should be made available on a regular basis through budgeting, to sustain current CSR activities and make financial provision for future projects.

\section{References}

Ackerman, R.W. (1975), The Social Challenge to Business, Harvard University Press, Cambridge, MA.

Ahmed, N. Z., R. V. Montagno and R. J. Firenze. (1998), 'Organizational Performance and Environmental Consciousness: An Empirical Study', Management Decision 36(2), 57-62.

Alvarez, G. M. J., J. J. Burgos and L. J. J. Cespedes. (2001), 'An Analysis of Environmental Management, Organizational Context and Performance of Spanish Hotels', Omega 29(6), 457-471.

Aupperle, K.E., Carroll, A.B., \& Hatfield, J.D. (1985). An empirical examination of the relationship between corporate social responsibility and profitability. Academy of Management Journal, 28(2), 446-463.

Berman, S. L., A. C., Wicks, S., Kotha and Jones. (1999). 'Does Stakeholder Orientation Matter? The Relationship between Stakeholder Management Models and Firm Financial Performance', Academy of Management Journal 42(5), 488-506.

Bhattacharya, C. B., and Sen, S. (2004). "Doing better at doing good: When, why, and how consumers respond to corporate social initiatives"; California Management Review, 47, $9-24$. 
Boulding, W. and Kirmani, M. A. (1993). 'A Consumer Side Experimental Examination of Signaling Theory: Do Consumers Perceive Warranties as Signals of Quality? Journal of Consumer Research 20(1), 111-128.

Bromiley, P. and Marcus, A. (1989). 'The Deterrent to Dubious Corporate Behavior: Profitability, Probability and Safety Recalls', Strategic Management Journal 10(3), 233-250.

Brown, T. J. and Dacin, P. A. (1997). 'The Company and the Product: Corporate Associations and Consumer Product Responses', Journal of Marketing 61(1), 68-85.

Carroll, A. B. (1979). A three-dimensional conceptual model of corporate performance, The Academy of Management Review, 4, 497-505.

Christman, P. (2000). 'Effects of “Best Practices" of Environmental Management on Cost Advantage: The Role of Complementary Assets', Academy of Management Journal 43(4), 663680 .

Clair, J. A., Milliman, J and Mitroff, I. I. (1995). 'Clash or Cooperation? Understanding Environmental Organizations and Their Relationships to Business', in J. E. Post (ed.) and D.

Clarkson, M. B. E. (1995). 'A Shareholder Framework for Analyzing and Evaluating Corporate Social Performance', Academy of Management Review 20(1), 571-610.

CLSA (Credit Lyonnais Securities Asia): October 2000, 'Report on Corporate Governance: Emerging Markets Equities Research', http://web.management.mcgill. ca/Art.Durnev/clsa_2000.pdf. Accessed 5 January2017.

Collins, A and M. Starik (Vol. eds.), Research in Corporate Social Performance and Policy: Sustaining the Natural Environment - Empirical Studies on the Interface between Nature and Organizations (JAI Press, Greenwich, CT), Supplement 1,163-193.

Coombes, P. and Watson, M. (2000). 'Three Surveys on Corporate Governance', McKinsey Quarterly 4, 74-77.

Davidson, W. N. and Worell, D. L. (1988). 'The Impact of Announcements of Corporate Illegalities on Shareholder Returns', Academy of Management Journal 31(1), 195-200.

Donaldson, T., \& Preston, L.E. (1995). The stakeholder theory of the corporation: Concepts,

evidence and implications. Academy of Management Review, 20(1), 65-91.

Dutton, J. E., Dukerich, J. M. and Harquail, C. V. (1994). 'Organizational Images and Member Identification', Administrative Science Quarterly 39(2), 239-263.

Freeman, R. E. (1984). Strategic Management: A Stakeholder Approach. Pitman Publishing, Boston, MA).

Etisalat Telecommunications U.A.E (2016). Annual Report. www.etisalat.com

Ferrell, O.C., Gonzalez-Padron, T.L., Hult, T.M. and Maignan, I. (2010). “From market orientation to stakeholder orientation", Journal of Public Policy \& Marketing, Vol. 29 No. 1, 93-96.

Fombrun, C.J. (1996). Reputation: Realising Value from the Corporate Image, Harvard Business School Press, Boston, MA.

Fomburn, C. and M. Shanley: 1990, 'What's in a Name? Reputation Building and Corporate Strategy', Academy of Management Journal 33(2), 233-258. 
Gildea, R. L. (1994). 'Consumer Survey Confirms Corporate Social Action Affects Buying Decisions', Public Relations Quarterly 39(4), 20-22.

Golob, U. and Bartlett, J. (2007). "Communicating about corporate social responsibility: a comparative study of CSR reporting in Australia and Slovenia", Public Relations Review, Vol. 33 No. 1, 1-9.

Greening, D. W. and D. B. Turban (2000). 'Corporate Social Performance as a Competitive Advantage in Attracting a Quality Workforce', Business \& Society 39(3), 254-280.

Graves, S. and Waddock, S. (1994). 'Institutional Owners and Corporate Social Performance', Academy of Management Journal 37(4), 1034-1046.

Greeno, J. L. and Robinson, S. N. (1992). 'Rethinking Corporate Environmental Management', Columbia Journal of World Business 27(3-4), 222-232.

Griffin, J. J. and Mahon, J. F. (1997). 'The Corporate Social Performance and Corporate Financial Performance Debate', Business \& Society 36(1), 5-31.

Handelman, J. M. and Arnold, S. J. (1999). 'The Role of Marketing Actions with a Social Dimension: Appeals to the Institutional Environment', Journal of Marketing 63(3), 33-48.

Hayes, A. S. and Pereira, J. (September 20 1990). 'Facing a Boycott, Many Companies Bend', Wall Street Journal, 1- 24.

Herremans, I. and Ryans, J.K. Jr. (1995). “The case for better measurement and reporting of market performance", Business Horizon, Vol. 38 No. 5, 51-60.

Hoeffler, S. and Keller, K. L. (2002). 'Building Brand Equity Through Corporate Societal Marketing', Journal of Public Policy and Marketing 21(1), 78-89.

Husted, B. W. (2003). 'Governance Choices for Corporate Social Responsibility: To Contribute, Collaborate or Internalize?’ Long Range Planning 36(5), 481-498.

Kirmani, A. (1997). 'Advertising Repetition as a Signal of Quality: If It's Advertised So Much, Something Must Be Wrong', Journal of Advertising 26(3), 77-90.

Koys, D. J. (2001). 'The Effects of Employee Satisfaction, Organizational Citizenship Behavior, and Turnover on Organizational Effectiveness: A Unit-Level, Longitudinal Study', Personnel Psychology 54(1), 101-114.

Lii, Y.S.; Lee, M. (2012).“Doing right leads to doing well: when the type of CSR and reputation interact to affect consumer evaluations of the firm"; Journal of Business Ethics; 105, 69-81.

Maignan, I. and Ferrell, O. C. (2001). 'Corporate Citizenship as a Marketing Instrument Concepts, Evidence and Research Directions', European Journal of Marketing 35(3/4), 457-484.

Maignan, I., \& Ferrell, O.C. (2004). Corporate social responsibility and marketing: An integrative framework, Journal of the Academy of Marketing Science, 32, 519.[Crossref], [Web of Science $®]$ [Google Scholar]

Maignan, I., Gonzalez-Padron, T.L., Hult, G.T.M. and Ferrell, O.C. (2011). "Stakeholder orientation: development and testing of a framework for socially-responsible marketing", Journal of Strategic Marketing, Vol. 19 No. 4, 313-338.

Margolis, J. D. and Walsh, J. P. (2003). 'Misery Loves Companies: Rethinking Social Initiatives by Business', Administrative Science Quarterly 48(2), 268-305. 
Matten, D., \& Moon, J. (2008). 'Implicit' and 'explicit' CSR: A conceptual framework for a comparative understanding of corporate social responsibility. Academy of Management Review,

33(2), 404-424.

McGuire, J. B., Sundgren, A. and Schneeweis, T. (1988).Corporate Social Responsibility and Firm Financial Performance', Academy of Management Journal 31(4), 854-872.

McWilliams, A. and Siegel, D. (2001). Corporate Social Responsibility: a Theory of the Firm Perspective, Academy of Management Review, 26 (1), 117-127.

Miles, M.P., Munilla, L.S. and Darroch, J. (2006). “The role of strategic conversations with

stakeholders in the formation of corporate social responsibility strategy", Journal of Business Ethics, Vol. 69 No. 2, 195-205.

Neville, B.A., Bell, S.J. and Menguc, B. (2005). “Corporate reputation, stakeholders and the social performance-financial performance relationship", European Journal of Marketing, Vol. 39 Nos 9/10, 1184-1198.

Orlitzky, M., Schmidt, F. L. and Rynes, S. L. (2003). 'Corporate Social and Financial Performance: A Meta-Analysis', Organization Studies 24(3), 403-411.

Owen, C. L. and Scherer, R. F. (1995). 'Social Responsibility and Market Share', Review of Business 15(1), 11-17.

Oskamp, S. (1997).Attitudes and Opinions, 2nd edition. Englewood Cliffs, NJ: Prentice Hall.

Pirsch, J., Gupta, S., \& Grau, S. L. (2007). A framework for understanding corporate social responsibility programs as a continuum: An exploratory study. Journal of Business Ethics, 70, 125-140.10.1007/s10551-006-9100-y[Crossref], [Web of Science ®][Google Scholar]

Porter, M. E., \& Kramer, M. R. (2006). Strategy \& society: The link between competitive advantage and corporate social responsibility. Harvard Business Review, 84, 5668.[Google Scholar]

Kotler, P. (2005). Marketing Management.11th edition. Prentice Hall London.

Kramer, M. R. (2011). Creating shared value. Harvard Business Review, 89, 62-77.[Web of Science $\circledR][$ Google Scholar]

Lee, M. P. (2008). 'A Review of the Theories of Corporate Social Responsibility: Its Evolutionary Path and the Road Ahead', International Journal of Management Reviews 10(1), 53-73.

Riordan, C. M., Gatewood, R. D. and Bill, J. B. (1997). 'Corporate Image: Employee Reactions and Implications for Managing Corporate Social Performance', Journal of Business Ethics 16(4), 401-412.

Russo, M. V. and Fouts, P. A. (1997). 'A Resource Based Perspective on Corporate Environmental Performance and Profitability', Academy of Management Journal 40(3), 534-559.

Sen, S. and Bhattacharya, C. B. (2001). 'Does Doing Good Always Lead to Doing Better? Consumer Reactions to Corporate Social Responsibility', Journal of Marketing Research 38(2), 225-243. 
Sen, S., Bhattacharya, C. B. and Korschun, D. (2006). 'The Role of Corporate Social Responsibility in Strengthening Multiple Stakeholder Relationships: A Field Experiment', Journal of the Academy of Marketing Science 34(2), 158-166.

Somavia, J. (2000). 'Business. Its Direct Stake in Putting Human Needs First', UN Chronicle $37(2), 42$.

Teoh, S. H., Welch, I. and Wazzan, C. P. (1999). 'The Effect of Socially Activist Investment Policies on the Financial Markets: Evidence from the South African Boycott', Journal of Business 72(1), 35-89.

Turban, D. B. and Greening, D. W. (1997). 'Corporate Social Performance and Organizational Attractiveness to Prospective Employees', Academy of Management Journal 40(3), 658763.

Waddock, S. A. and Graves, S. B. (1997), 'The Corporate Social Performance - Financial Performance Link', Strategic Management Journal 18(4), 303-320.

Wing-Hung Lo, C., Fryxell, G.E. and Tang, S.Y. (2010). “Stakeholder pressures from perceived environmental impacts and the effect on corporate environmental management programmes in China", Environmental Politics, Vol. 19 No. 6, 888-909.

Wood, D. J. (1991). 'Corporate Social Performance Revisited', Academy of Management Review 16(4), 691- 718 .

Wright, P. and Ferris, S. (1997). 'Agency Conflict and Corporate Strategy: The Effect of Divestment on Corporate Value', Strategic Management Journal 18(1), 77-83.

Yamane, T. (1964). Statistics: An Introduction Analysis. 3rd. ed. New York: Harper and Row Publishers.

Yoon, E., Guffey, H. and Kijewski, V. (1993). "The Effects of Information and Company reputation on intentions to buy a business service", Journal of Business Research, 27(3), 215- 228.

Youndt, M., S., Snell, J., Dean, I. and Lepak, D. (1996). 'Human Resource Management Manufacturing Strategy and Firm Performance', Academy of Management Journal 39(4), 836-866. 